\title{
Empowerment of Household Women Joined in The Mandiri Women Group in The New Normal Era in Bandar Labuhan Village, Tanjung Morawa District, Deli Serdang District
}

\author{
Ritha F Dalimunthe ${ }^{1 *}$, Herfita Rizki Hasanah Gurning ${ }^{1}$, Ameilia Zuliyanti Siregar ${ }^{1}$, Hairani \\ Siregar $^{1}$, Arif Qaedi Hutagalung ${ }^{1}$ \\ ${ }^{1}$ Faculty of Economics and Business, University Sumatera Utara, Medan, Indonesia \\ *Email: rithadalimunthe@gmail.com
}

\begin{abstract}
Housewives who are members of the women's community can minimize the impact of the Corona 19 Virus by empowering women through training and mentoring activities to make changes in lifestyle or lifestyle so that they become housewives who understand what it means about working and doing business from home, as well as maintaining distance, living healthy and communicate online. This activity also introduces the use of yardland to optimize housewives as human resources in empowering family-based housewives. Housewives, if trained and accompanied, can be at the forefront of maintaining and providing understanding for the family. This can be done through training and mentoring for housewives who are members of the 9 independent women's community groups in Bandar Labuhan Village, Tanjung Morawa District, Deli Serdang Regency, North Sumatra who will become cadres for members. other communities or interested housewives. Then from the students, 2 people were chosen to be trained to be motivators
\end{abstract}

Keyword: Service, Community of Women

\begin{abstract}
Abstrak
Ibu rumah tangga yang tergabung dalam komunitas perempuan dapat meminimalkan dampak Virus Corona 19 dengan pemberdayaan perempuan melalui kegiatan pelatihan dan pendampingan untuk melakukan perubahan pola hidup atau gaya hidup sehingga menjadi ibu rumah tangga yang paham artinya tentang bekerja dan berusaha dari rumah, serta menjaga jarak, hidup sehat serta berkomunikasi online. Kegiatan ini juga memperkenalkan pemanfaatan lahan pekarangan untuk mengoptimalkan Ibu rumah tangga sebagai sumber daya manusia dalam pemberdayaan ibu rumah tangga yang berbasis pada keluarga. Para Ibu rumah tangga jika dilatih dan di dampingi dapat menjadi garda terdepan dalam menjaga dan memberikan pemahaman bagi keluarga. Hal ini dapat dilakukan melalui cara pelatihan serta pendampingan bagi para Ibu rumah tangga yang tergabung dikelompok komunitas perempuan wanita mandiri yang berjumlah 9 orang yang berada di Desa Bandar Labuhan, Kec. Tanjung Morawa, Kab.Deli Serdang, Sumatera Utara yang akan menjadi kader bagi anggota komunitas lainnya atau ibu rumah tangga yang berminat. Kemudian dari Mahasiswa di pilih 2 orang untuk dilatih menjadi motivator.
\end{abstract}

Kata Kunci: Pengabdian, Komunitas Perempuan

\section{PENDAHULUAN}

Mitigasi bencana seperti Covid 19 disuatu kota tergantung pada kualitas Sumber Daya Manusia di wilayah tersebut. Sumber daya manusia seperti ibu rumah tangga seharusnya memiliki kualitas dalam meningkatkan kesejahteraan masyarakat dengan melakukan perubahan dalam keluarga serta berperan aktif dalam melakukan mitigasi bencana. Oleh karena itu sumber daya manusia dapat mengoptimalkan dirinya agar bisa mengatasi permasalahan sehingga tidak terjadinya serta angka kematian yang tinggi ditengah masyarakat.

Permasalahan Covid 19 dapat diperkecil dengan cara mengarahkan masyarakat agar dapat mengubah pola hidup atau gaya hidup dengan melakukan adaptasi diera pandemic melalui aktivitas yang lebih banyak bekerja dan berusaha dari rumah. Berdasarkan peraturan pemerintah yang 
mengharuskan setiap orang dapat mengelola dan berani mengubah pola dan cara hidupnya yang dilakukan dari rumah mulai dengan melakukan jaga jarak serta menjaga kebersihan dengan selalu mencuci tangan dan menggunakan masker dan hidup bersih. Disamping itu ibu rumah tangga haruslah memiliki sikap mental yang selalu positif serta aktif meningkatkan ketahanan keluarga melalui kegiatan pemberdayaan melalui penanaman sayuran seperti cabe ataupun kangkung.

Perempuan sebagai ibu rumah tangga diharapkan memiliki kemampuan untuk berusaha mengatasi masalah yang timbul akibat virus Covid 19 disamping menjadi anggota masyarakat dan istri serta ibu dalam keluarga. Oleh karena itu pemberdayaan masyarakat di suatu desa diperlukan untuk menjadikan ibu rumah tangga yang mampu menjalani kehidupan ditengah tengah terjadinya virus Covid 19. Para ibu rumah tangga jika dilatih dan didampingi dapat menjadi ibu rumah tangga yang siaga dalam mengatasi permasalahan akibat virus Covid 19 ini. Hal ini dapat dilakukan melalui cara pendampingan para ibu rumah tangga yang berminat memanfaatkan lahan pekarangan untuk menanam sayuran. Adanya keterbatasan kemampuan serta keahlian para perempuan dalam memahami Covid 19 serta dampaknya perlu adanya pelatihan dan pendampingan bagi ibu rumah tangga untuk dapat memahami manfaat menjaga jarak serta hidup yang berkelanjutan sehingga dapat mengerti dan melakukan protocol atau cara yang benar. Adapun Pengabdian masyarakat dalam dosen wajib mengabdi dilakukan di Desa Bandar labuihan Kecamatan Tanjung Morawa yaitu para ibu rumah tangga yang berada pada komunitas perempuan.

\section{Permasalahan Mitra}

Ibu rumah tangga yang tergabung dalam komunitas perempuan belum dapat memahami tentang pentingnya menjalankan aktivitas dari rumah, menjaga jarak, menjaga kebersihan dengan mencuci tangan, menggunakan masker serta memanfaatkan lahan pekarangan untuk menanam sayuran seperti kangkung, cabe dan sebagainya sehingga tetap makan makanan sehat serta dapat mengelola ekonomi keluarga agar dapat memperkecil dampak dari virus Covid 19 dan bahkan ikut serta dalam menghilangkan virus ditengah keluarga.

Berdasarkan focus group discussion pada kelompok ibu rumah tangga di desa Bandar labuhan kecamatan Tanjung Morawa yang tergabung dalam komunitas perempuan memiliki permasalahan sebagai mitra, antara lain:

1) Kondisi ekonomi yang sulit mengharuskan ibu rumah tangga harus aktif memanfaatkan waktu untuk mengurangi belanja keluarga dengan memanfaatkan lahan pekarangan untuk menghasilkan sayuran.

2) Masih banyak Ibu rumah tangga yang terbatas pemahamannya untuk berkomunikasi online dengan baik dan benar.

Anggota komunitas perempuan sebagian besar belum mememahami perlunya mencuci tangan, menggunakan masker, menjaga jarak dan tetap bekerja dan berusaha dari rumah.

\section{METODE PELAKSANAAN}

Metode yang dipakai di dalam kegiatan pengabdian kepada masyarakat dengan judul Pemberdayaan Ibu Rumah Tangga Yang Tergabung Dalam Kelompok Wanita Mandiri Pada Era New Normal Di Desa Bandar Labuhan Kecamatan Tanjung Morawa Kabupaten Deli Serdang adalah dengan melakukan sosialisasi yang disampaikan oleh Prof. Dra. Pujiati, M. Soc.Sc., Ph, D dan dihadiri oleh 9 orang ibu rumah tangga untuk menciptakan pemahaman tentang pentingnya berprilaku hidup sehat dimasa covid 19.

Adapun tahapan kegiatannya adalah sebagai berikut:

1) Memperkenalkan Covid 19 dan permasalahan yang dapat ditimbulkannya

2) Melakukan Fokus Group Discussion komunitas perempuan

3) Mengidentifikasi masalah yang dihadapi oleh kelompok Ibu rumah tangga Mandiri Warna Warni

4) Pelatihan dilaksanakan sehari melalui ceramah, serta latihan dengan rincian materi 
5) Prinsip dasar perubahan gaya hidup stay at home dari Rumah Ratu Salmah kepada para Ibu rumah tangga

6) Latihan penggunaan IT untuk komunikasi online komunitas ibu rumah tangga dari rumah inspirasi Ratu Salmah

7) Tim akan berkunjung sekali dan bertelephone untuk melihat pada komunitas ibu rumah tangga

8) Tim akan memfasilitasi pembuatan pemanfaatan lahan pekarangan

\section{HASIL DAN PEMBAHASAN}

\subsection{Peserta Pengabdian}

Pengabdian ini melibatkan pengembangan kelompok mitra, yaitu kelompok Wanita Mandiri Warna-Warni di Desa Bandar Labuhan, Kecamatan Deli Serdang, Sumatera Utara. Pada pelaksanaan kegiatan pengabdian ini, diikuti oleh 9 orang anggota yang merupakan ibu rumah tangga.

Kegiatan ini dilakukan dengan melihat potensi yang terdapat pada komunitas perempuan yang tergabung dalam kelompok berjumlah minimal 9 orang yang dilatih dari rumah tangga yang ada di daerah orang akan menjalani pendampingan selama 3 bulan setelah memberikan masukan berupa pelatihan kepada Ibu rumah tangga untuk dapat memahami tentang pola hidup pada era Covid 19 sesuai hasil dari observasi dan diskusi yang telah dilakukan.

Pendataan karakteristik anggota komunitas mitra yang mengikuti kegiatan pengabdian telah terdata sebanyak 9 orang anggota yang sebelumnya telah mengikuti pelatihan. Karakteristik ini dikelompokkan berdasarkan jenjang pendidikan, dirangkum dalam Gambar 3.1.

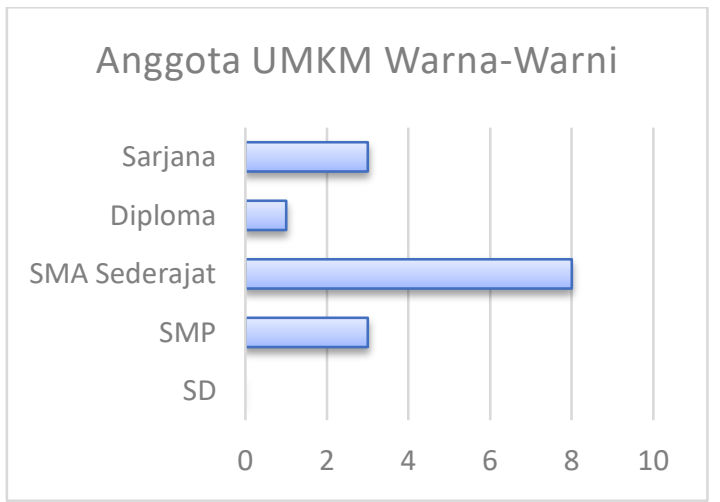

Gambar 3.1. Mitra Berdasarkan Pendidikan Terakhir

Gambar 3.1 menunjukkan bahwa mayoritas dari anggota kelompok Wanita Mandiri WarnaWarni memiliki jenjang pendidikan terakhir pada jenjang SMA atau sederajatnya. Pada kondisi saat ini, tuntutan keahlian dan pendidikan tenaga kerja memerlukan kualifikasi yang tinggi (Indonesian Statistics Bureau, 2017). Oleh karena itu, banyak dari mereka merasa sulit mendapatkan pekerjaan yang diharapkan, meskipun memang sebagian memilih fokus untuk menjaga peran sebagai ibu rumah tangga.

Seluruh anggota kelompok ini adalah perempuan dan secara kebetulan semuanya adalah ibu rumah tangga yang harus berbagi peran antara mengurus rumah tangga dan mendukung kebutuhan ekonomi. Fleksibilitas waktu dalam bekerja menjadi kunci dalam menyeimbangkan kedua peran sekaligus. Dari sisi usia, dua dari lima belas anggota komunitas masih berusia 30 tahun ke bawah. Artinya komunitas ini memiliki dua orang wirausaha muda. Selebihnya adalah ibu-ibu rumah tangga yang berusia sampai dengan 53 tahun.

\subsection{Hasil Pelaksanaan Kegiatan}

Kegiatan Pengabdian yang dilaksanakan dalam program Dosen Wajib Mengabdi kali ini dipersiapkan dan dilaksanakan dalam fokus pemberdayaan perempuan, khususnya ibu-ibu rumah tangga di Desa Bandar Labuhan Kecamatan Tanjung Morawa yaitu bagi ibu rumah tangga yang berada pada komunitas perempuan. Pemberdayaan masyarakat melalui kegiatan pengabdian kali ini 
difokuskan pada penciptaan pemahaman pentingnya berprilaku hidup sehat dimasa covid 19. Tim pengabdian telah melakukan sosialisasi dan pendampingan yang disampaikan oleh Prof. Dra. Pujiati, M. Soc.Sc., Ph, D yang dapat dilihat pada Gambar 3.2.

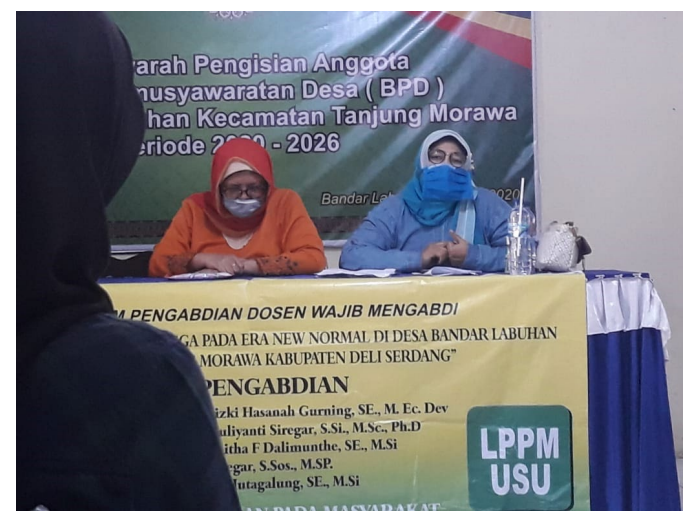

Gambar 3.2. Sosialisasi Oleh Prof. Dra Pujiati, M. Soc.Sc., Ph, D

Kegiatan pengabdian ini fokus pada pemahaman ibu rumah tangga tentang perubahan perilaku kearah pola hidup pada masa adaptasi baru serta penggunaan lahan di pekarangan rumah sebagai tempat bercocok tanam pada kegiatan pengabdian ini, sosialisasi dihadiri oleh 9 orang ibu rumah tangga serta komunikasi online disampaikan oleh Aprinta Surbakti, M.M. Selain itu juga diberikan bibit cabe dan kangkung untuk melengkapi kegiatan bercocok tanam yang telah disosialisasikan.

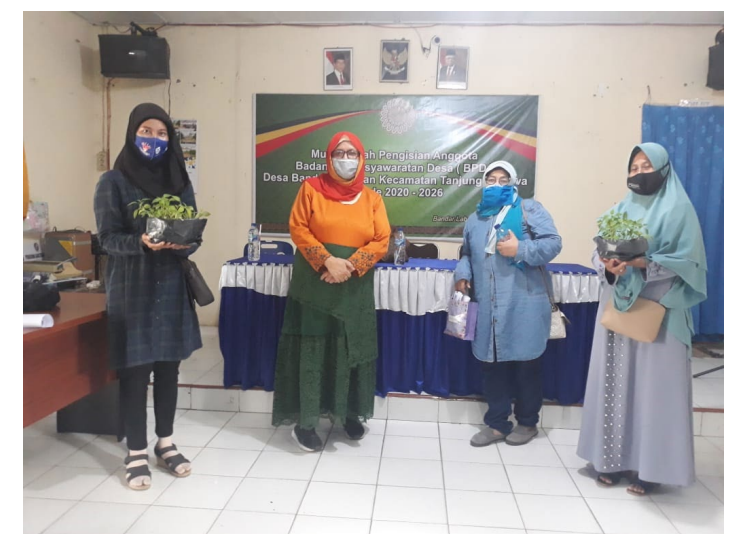

Gambar 3.3. Pemberian bibit cabe dan kangkung

Dari rumah inspirasi Ratu Salmah untuk membantu melakukan pemberdayaan perempuan yang menjadi komunitas wanita di daerah pengabdian kepada masyrakat. Dalam kesempatan ini pula tim pengabdian mengundang perwakilan pemberdayaan desa setempat untuk melihat pemberian bibit cabe kepada peserta agar menanam dirumah.

\section{KESIMPULAN (}

Dari hasil pelaksanaan kegiatan pengabdian kepada masyarakat yang telah dilaksanakan oleh tim pelaksana pengadian masyarakat dengan judul Pemberdayaan Ibu Rumah Tangga Yang Tergabung Dalam Kelompok Wanita Mandiri Pada Era New Normal Di Desa Bandar Labuhan Kecamatan Tanjung Morawa Kabupaten Deli Serdang, didapatkan kesimpulan sebagai berikut:

1) Pelatihan dan pendampingan terhadap pemahaman pentingnya berprilaku hidup sehat dimasa covid 19.

2) Faktor eksternal lainnya adalah adanya protokol kesehetan yang mengharuskan jaga jarak dan tidak bisanya melakukan penjualan offline tanpa aturan protokol kesehatan 
3) Faktor eksternal yang mempengaruhi pelatihan dan pendampingan dalam pemberdayaan perempuan sebagai ibu rumah tangga untuk melakukan ketahanan keluarga dengan menanam sayur di lahan pekarangan.

4) Adanya dukungan aparat Desa Bandar Labuhan dan Kecamatan serta Pemerintah Kabupaten Deli Serdang dalam meningkatkan UMKM

Adapun yang menjadi saran yaitu:

1) Ibu rumah tangga yang tergabung dalam komunitas Wanita Mandiri WarnaWarni sebaiknya melakukan aktivitas sehari-hari mengikuti protocol kesehatan serta melakukan komunikasi dengan online untuk menjaga jarak selama masa pandemic Covid 19.

2) Pemerintah desa, kecamatan serta Kabupatan sebaiknya melakukan terus menerus sosialisasi dan memberikan sanksi kepada masyarakat yang tidak ikut dalam protocol kesehatan

3) Perguruan tinggi merupakan mitra yang berkelanjutan dalam pemberdayaan masyarakat untuk ketahanan keluarga dalam memperkecil dampak Covid 19 serta memanfaatkan lahan pekarangan di desa Bandar Labuhan Kecamatan Tanjung Morawa

\section{UCAPAN TERIMAKASIH}

Ucapan terima kasih sebesar-besarnya kepada Universitas Sumatera Utara yang telah mendanai Kegiatan Pengabdian Kepada Masyarakat ini. Penulis juga mengucapkan terima kasih kepada kelompok Wanita Mandiri Warna-warni serta pemerintah Tanjung Morawa yang mendukung pelaksanaan kegiatan pengabdian ini. Semua pihak yang membantu dalam pegabdian masyarakat maupun penelitian wajib dituliskan di bab ccapan terimakasih ini.

\section{DAFTAR PUSTAKA}

Setyawan, Purnomo. (2009). Menumbuhkan Kebiasaan Menyusun Laporan Keuangan pada Usaha Kecil dan Menengah. Jurnal Bisnis dan Usahawan, II No. 7

Sethuraman., S.U., (1993), The Urban Informal Sector in Developing Countries, International Labor Organizati on, Jenewa.

Kementerian Keuangan Republik Indonesia. (2011). Potensi Perusahaan UKM untuk Go Public. Badan Pengawas Pasar Modal Dan Lembaga Keuangan, Depkeu RI. Jakarta

Kementerian Perdagangan RI. (2009). Kajian Potensi Pengembangan Pasar Jamu. Pusat Penelitian Dan Pengembangan Perdagangan Dalam Negeri Badan Penelitian Dan Pengembangan Perdagangan Kementerian Perdagangan. Jakarta

Susilo, S.Y. (2007). Masalah dan Dinamika Usaha Kecil: Studi Empiris Pedagang Klithikan di Alun-alun Selatan Yogyakarta. Jurnal Ekonomi. Vol. 12 No. 01 Maret 2007

Susilo, S.Y. \& Krisnadewara, P.D. (2007). Strategi Bertahan Industri Kecil Pascagempa Bumi di Yogyakarta. Jurnal Ekonomi dan Bisnis, Vol. 9 No. 2, Juni 2007. 